\title{
Estimasi penggunaan bahan jaring (webbing) dan panjang tali pemberat pada pukat cincin kecil di Sulawesi Utara
}

\author{
Estimation on the use of webbing material and lead line length on small purse seine in \\ North Sulawesi
}

ISROJATY J. PARANSA*

Program Studi Pemanfaatan Sumberdaya Perikanan, Fakultas Perikanan dan Ilmu Kelautan, Universitas Sam Ratulangi, Manado 95115

\begin{abstract}
The length of small purse seines in North Sulawesi highly varies based on 14 units measured. It ranges from 255.00 $\mathrm{m}$ long to $450.00 \mathrm{~m}$ long, and $66.00 \mathrm{~m}$ wide to $105.00 \mathrm{~m}$ wide with the same length of float line and lead line, despite different shape. The lead line length is not consistent with number of net used. The purpose of the cross- cutting is to follow the shape of the hipotenusa as a result of difference in net width on each part. Number of meshes that should be tied on the lead line will rise depending upon the cutting shape composition, in which the rest of mesh number towards the cross-cutting of the widest part near the side line part, is number of bars as multiplication of total mesh difference by two. Increase in number of bars will automatically add the length of lead line on that part with proportional distribution, so that the net on this part will open with the area, and the net will be set along the lead line. Thus, it is expected to be able to prevent net piling on certain parts that usually become one of the causes of net twisting on the purse line that inhibits the ring line pulling process. This study was done using a descriptive method with case study concerning an object in order to provide systematic, factual, and accurate description on the facts. A case study intensively and carefully looks at certain case of limited objects (Arikunto, 1998). The case studied is the ratio of float line and lead line and the area covered by the net based on the net shape after set using the cutting rate. Results showed that the slope side can be set on the net using the cutting ratio based on the difference between vertical number of meshes and horizontal number of meshes, there was excessive usage of webbing materials on nine small purse seines and insufficient materials on four purse seines, and total length of the lead line was different between the analytical output and that set on the small purse seine.
\end{abstract}

Keywords: cutting rate; webbing; hypotenuse; sinker line; purse seine

\begin{abstract}
ABSTRAK
Ukuran panjang pukat cincin kecil yang tersebar di beberapa wilayah Sulawesi Utara sangatlah bervariasi dari 14 buah pukat cincin kecil yang dilakukan pengukuran, variasi panjang mulai dari 255,00 meter sampai dengan 450,00 meter, dan lebar mulai dari 66,00 meter sampai dengan 105,00 meter yang memiliki panjang tali pelampung dan panjang tali pemberat cenderung sama. walaupun bentuk jaring pada bagian-bagian tersebut tidaklah sama. Panjang tali pemberat yang seharusnya terpasang, tidak sesuai dengan banyaknya daging jaring yang digunakan. Tujuan dari pemotongan miring adalah untuk mengikuti bentuk sisi miring (hipotenusa) akibat adanya perbedaan lebar jaring pada masingmasing bagian. Jumlah mata jaring yang seharusnya diikatkan pada tali pemberat akan bertambah tergantung pada komposisi bentuk pemotongan, dimana selisih jumlah mata ke arah pemotongan miring dari bagian yang terlebar menuju bagian tali samping, merupakan jumlah bar dari hasil kali dua dengan selisih jumlah mata tersebut.Bertambahnya jumlah bar, dengan sendirinya akan menambah panjang tali pemberat pada bagian dimaksud dengan distribusi yang proporsional, sehingga lembaran jaring pada bagian ini akan terbentuk sesuai dengan luasan yang ada, dan mata jaring yang ada akan tertata pada sepanjang tali pemberat. Dengan demikian diharapkan dapat mencegah terjadinya penumpukan daging jaring pada bagian-bagian tertentu, yang biasanya merupakan salah satu penyebab terjadinya peristiwa terbelitnya daging jaring pada tali kolor, sehingga menghambat proses penarikan tali kolor. Penelitian ini dilakukan dengan metode deskriptif dengan studi kasus, yang meneliti suatu objek yang tujuannya untuk memberi gambaran secara sistematis, faktual dan akurat tentang fakta. Sedangkan studi kasus adalah mempelajari kasus tertentu pada objek yang terbatas secara intensif, terinci, dan mendalam pada gejala tertentu
\end{abstract}

\footnotetext{
*Email: iparansa@yahoo.com
} 
(Arikunto, 1998). Kasus yang dipelajari adalah perbandingan panjang tali pelampung dengan tali pemberat serta luas area yang seharusnya tertutupi oleh jaring berdasarkan bentuk jaring setelah ditata dengan menggunakan cutting rate. Hasil penelitian ini menunjukkan, sisi miring dapat terbentuk pada jaring dengan menggunakan cutting ratio berdasarkan selisih jumlah mata vertikal sebagai ketinggian jaring dan horizontal sebagai panjang jaring, terdapat kelebihan pemakaian bahan jaring pada sembilan buah pukat cincin kecil dan kekurangan bahan pada empat buah dan keseluruhan panjang tali pemberat tidak sama antara hasil analisis dengan panjang tali yang terpasang pada pukat cincin kecil.

Kata-kata kunci: cutting ratio; bahan jaring; sisi miring; tali pemberat; pukat cincin

\section{PENDAHULUAN}

Pukat cincin (purse seine) pertama kali diperkenalkan di pantai utara Jawa oleh BPPL (LPPL) pada tahun 1970 dalam rangka kerjasama dengan pengusaha perikanan di Batang (Bpk. Djajuri) dan berhasil dengan baik. Kemudian diaplikasikan di Muncar (1973/1974) dan berkembang pesat sampai sekarang. Pada awal pengembangannya di Muncar sempat menimbul-kan konflik sosial antara nelayan tradisional dengan nelayan pengu-saha yang menggunakan pukat cinicn. Namun akhirnya dapat diterima juga. Pukat cincin ini memang potensial dan produk-tivitas hasil tang-kapannya tinggi. Dalam perkem-bangannya terus mengalami penyempurnaan tidak hanya bentuk (konstruksi) tetapi juga bahan dan perahu/kapal yang digunakan untuk usaha perikanannya.

Alat tangkap pukat cincin, di Sulawesi Utara lebih dikenal dengan nama "soma pajeko" merupakan salah satu alat tangkap yang memiliki perkembangan yang baik, karena alat tangkap ini sangat efektif untuk menangkap ikan pelagis kecil yang bergerombol dengan kepadatan yang tinggi (Katiandagho, 1989). Jenis-jenis ikan pelagis yang menjadi tujuan penangkapan, pada umumnya adalah ikan pelagis kecil seperti kembung, layang, sardin, selar dan tongkol.

Pukat cincin kecil yang dikenal di Sulawesi Utara, pada umumnya dioperasikan dengan alat bantu penangkapan rumpon dan perahu lampu dengan menggunakan sistem satu kapal. Tipe pukat cincin kecil ini, menggunakan jaring yang tidak terlalu panjang tetapi agak dalam karena gerombolan ikan yang terkonsentrasi di bawah lampu ataupun rumpon, tidak bergerak terlalu menyebar melebar secara horizontal, akan tetapi cenderung bergerombol membentuk ketebalan tertentu secara vertikal. Ukuran lebar jaring harus cukup dalam untuk dapat menangkap gerombolan ikan mulai permukaan sampai dengan kedalaman tertentu.
Ukuran panjang pukat cincin kecil yang tersebar di beberapa wilayah Sulawesi Utara sangatlah bervariasi. Pada penelitian ini, variasi panjang pukat cincin kecil mulai dari 222,50 meter sampai dengan 450,00 meter, dengan lebar mulai dari 66,00 meter sampai dengan 100,00 meter.

Umumnya pukat cincin kecil buatan nelayan tidak menggunakan tappering sehingga pada bagian sayap dan bahu terjadi kelebihan dan kekurangan penggunaan bahan jaring. Kelebihan dan kekurangan bahan jaring pada bagian sayap dan bahu dapat mengakibatkan terbelitnya jaring pada tali kolor. Kemudian panjang tali pelampung dan tali pemberat adalah sama karena nelayan beranggapan bahwa dengan panjang tali pelampung dan tali pemberat sama maka jaring akan cepat membentuk kantong, padahal sebaliknya jaring akan menyerupai dinding yang rata (plate) dan dapat mengganggu keberhasilan operasi penangkapan ikan.

Perhitungan yang dilakukan menunjukkan bahwa banyaknya jaring yang terpakai sesuai dengan bentuk yang nelayan inginkan cenderung tidak sesuai dengan yang seharusnya dipakai untuk mendapatkan bentuk yang dimaksud. Kondisi ini terlihat seakan jaring yang dipakai lebih hemat, padahal luasan bidang yang tertutupi oleh jaring tidak sesuai. Untuk itu perlu dicari alternatif pemecahan permasalahan diatas untuk kesesuaian luasan bahan jaring bagi pukat cincin kecil yang efisien dan efektif.

Pada umumnya, pukat cincin kecil yang ada di Sulawesi Utara memiliki panjang tali pelampung dan panjang tali pemberat yang sama, walaupun bentuk jaring pada bagian-bagian tersebut tidaklah sama. Panjang tali pemberat yang seharusnya terpasang, tidak sesuai dengan banyaknya daging jaring yang digunakan, padahal seharusnya tidak demikian, karena jumlah mata jaring akan bertambah (bar) apabila dilakukan pemotongan miring. 
Pada jaring yang diamati tidak dilakukan pemotongan miring, sehingga jumlah mata jaring pada bagian tali pelampung dan tali pemberat tetap sama. Hal ini terjadi karena, bentuk miring pada bagian bawah dipaksakan dengan cara gathering antara lembar jaring yang satu dengan lembar jaring lainnya pada masing-masing bagian maupun antar bagian jaring, dengan distribusi sebaran penggabungan mata jaring yang tidak merata.

Untuk mendapatkan bentuk jaring yang sesuai pada bagian ini, panjang dan maka perlu dilakukan tailoring nets atau taper cuts sehingga didapatkan bentuk miring ataupun bentuk trapesium jaring. Pemotongan bagian jaring yang dikenal adalah $\mathrm{T}$ direction (T cut), $\mathrm{N}$ direction ( $\mathrm{N} c u t)$ bar atau (B cut). T-cut atau transversal adalah pemotongan arah mesh atau sejajar arah jaring, N-cut atau pemotongan normal adalah pemotongan tegak lurus arah jaring yaitu pada bagian point, dan bar cut yaitu pemotongan sejajar dengan mesh. Tujuan dari pemotongan miring adalah untuk mengikuti bentuk sisi miring (hipotenusa) akibat adanya perbedaan lebar jaring pada masing-masing bagian. Jumlah mata jaring yang seharusnya diikatkan pada tali pemberat akan bertambah tergantung pada komposisi bentuk pemotongan, di mana selisih jumlah mata ke arah pemotongan miring dari bagian yang terlebar menuju bagian tali samping, merupakan jumlah bar dari hasil kali dua dengan selisih jumlah mata tersebut.

Bertambahnya jumlah bar, dengan sendirinya akan menambah panjang tali pemberat pada bagian dimaksud dengan distribusi yang proporsional, sehingga lembaran jaring pada bagian ini akan terbentuk sesuai dengan luasan yang ada, dan mata jaring yang ada akan tertata pada sepanjang tali pemberat. Dengan demikian diharapkan dapat mencegah terjadinya penumpukan daging jaring pada bagian-bagian tertentu, yang biasanya merupakan salah satu penyebab terjadinya peristiwa terbelitnya daging jaring pada tali kolor yang kemudian masuk ke cincin, sehingga menghambat proses penarikan tali kolor.

Penelitian ini diharapkan dapat memberikan informasi ilmiah mengenai solusi bagaimana membentuk sisi miring/bentuk trapesium pada jaring di bagian tali pemberat; luasan bidang yang seharusnya tertutupi jaring berdasarkan jaring yang diamati dan membandingkannya dengan hasil analisis; panjang tali pemberat yang harus terpasang/digunakan pada jaring berdasarkan perbedaan lebar kantong dan panjang tali samping; dan dapat memberikan informasi yang berguna terutama untuk membuat disain pukat cincin kecil dengan penggunaan bahan yang efektif dan efisien sesuai dengan kebutuhan berdasarkan panjang dan lebar jaring yang akan dirancang.

\section{METODE PENELITIAN}

Tulisan ini didasarkan pada metode deskriptif dengan berdasarkan studi kasus. Metode deskriptif adalah suatu metode dalam meneliti suatu objek yang tujuannya untuk memberi gambaran secara sistematis, faktual dan akurat tentang fakta. Sedangkan studi kasus adalah mempelajari kasus tertentu pada objek yang terbatas secara intensif, terinci, dan mendalam pada gejala tertentu (Arikunto, 1998). Kasus yang dipelajari adalah proporsi perbandingan panjang tali pelampung dengan lebar kantong, perbandingan lebar kantong dengan tali samping, perbandingan panjang tali pelampung dengan tali pemberat serta luas area yang seharusnya tertutupi oleh jaring berdasarkan bentuk jaring setelah ditata dengan menggunakan cutting rate.

\section{Analisis data}

Nilai penggantungan jaring atau hang-in ratio $\left(E^{\prime}\right)$ pada masing-masing bagiannya dihitung dengan menggunakan formula yang dikemukakan oleh Nomura dan Yamazaki (1977):

$$
E^{\prime}=\frac{L-I}{L} \times 100 \%
$$

di mana $L=$ panjang jaring terentang sempurna $(\mathrm{m})$, dan $I=$ panjang tali ris $(\mathrm{m})$.

Perhitungan lebar jaring (dalam tertata, d) menggunakan formula:

$$
d=n \cdot m \sqrt{2 \cdot E^{\prime}-\left(E^{\prime}\right)^{2}}
$$

di mana $n=$ jumlah mata arah dalam, dan $m=$ besar mata jaring $(\mathrm{cm})$.

Komposisi pemotongan (cutting ratio, $R$ ) didapatkan dengan menggunakan persamaan yang dikemukakan Fridman (1988) sebagai berikut:

$$
R=M_{T} / M_{N}
$$

di mana $M_{T}=$ jumlah mata arah pemotongan $\mathrm{T}$, dan $M_{N}=$ jumlah mata arah pemotongan $\mathrm{N}$.

Hubungan lebar dengan panjang soma pajeko oleh katiandagho (1985) dinyatakan dengan: 


$$
k=\frac{\text { Lebar }(\text { bagian terlebar })}{\text { Panjang purse seine }}
$$

artinya:

$k=0,08-0,20 \quad$ Perbandingan proporsional

$\mathrm{k}<0,08 \quad$ Jaring dalam air ketika tali kolor ditarik akan terbentuk menyerupai papan (plate)

$\mathrm{k}>0,20 \quad$ Jaring sulit ditangani di atas kapal

$\mathrm{k}>0,3 \quad$ Untuk pukat cincin yang dioperasikan pada malam hari.

Pengukuran-pengukuran dilakukan pada panjang dan lebar jaring setelah ditata, meliputi panjang tali pelampung, panjang tali pemberat dan panjang tali samping. Juga dilihat nilai penggantungan pada masing-masing bagian jaring serta tipe cutting rate sesuai bentuk yang ada dan memberi alternatif bentuk potongan yang ideal. Kemudian ditampilkan dalam beberapa grafik dan tabel.

\section{HASIL DAN PEMBAHASAN}

Ukuran panjang pukat cincin kecil yang tersebar di beberapa wilayah Sulawesi Utara sangatlah bervariasi dari 14 buah pukat cincin kecil yang dilakukan pengukuran, dengan variasi panjang mulai dari 255,00 m sampai dengan 450,00 m, dan lebar mulai dari $66,00 \mathrm{~m}$ sampai dengan $100,00 \mathrm{~m}$. Hasil pengukuran ini ditampilkan pada Tabel 1.

Perbandingan lebar kantong dan panjang tali samping pada pukat cincin kecil buatan nelayan cenderung nilainya lebih besar dari 0,6. Hal ini disebabkan pandangan nelayan itu sendiri yang beranggapan bahwa semakin panjang tali samping mendekati lebar kantong maka jaring akan lebih baik dalam melakukan penangkapan ikan.

Begitu juga dengan pemahaman mengenai penataan jaring, dimana kebanyakan jaring yang dibuat cenderung mengejar arah panjang dan hal ini tentu saja akan mempengaruhi nilai penggantungan jaring pada arah lebar, di mana semakin kecil nilai hang-in ratio, maka akan semakin mengurangi lebar jaring. Pada Tabel 2 ditunjukkan distribusi nilai penggantungan jaring pada masingmasing bagiannya.

Tabel 1. Beberapa ukuran utama pukat cincin kecil di Sulawesi Utara

\begin{tabular}{|c|c|c|c|c|c|c|c|}
\hline \multirow[t]{2}{*}{ No } & \multirow[t]{2}{*}{ Nama Pukat Cincin } & \multicolumn{2}{|c|}{ Panjang (m) } & \multicolumn{2}{|c|}{ Lebar (m) } & \multirow{2}{*}{$k=L k / L f$} & \multirow{2}{*}{$L b / L k$} \\
\hline & & $\begin{array}{c}\text { Tali } \\
\text { Pelampung } \\
(L f)\end{array}$ & $\begin{array}{c}\text { Tali } \\
\text { Pemberat } \\
(L s)\end{array}$ & $\begin{array}{l}\text { Samping } \\
\quad(L b)\end{array}$ & $\begin{array}{c}\text { Kantong } \\
(L k)\end{array}$ & & \\
\hline 1 & Motabang, Bolmong & 446,00 & 446,00 & 74.96 & 105,00 & 0,24 & 0,71 \\
\hline 2 & Filadelfia, Sapa & 291,00 & 308,05 & 33,00 & 66,00 & 0,23 & 0,50 \\
\hline 3 & Dunia Bulat I, Batu Putih & 273,78 & 273,78 & 33,24 & 57,00 & 0,21 & 0,58 \\
\hline 4 & Kaisar Laut 2, Molompar & 237,00 & 273,00 & 47,54 & 72,00 & 0,30 & 0,66 \\
\hline 5 & Sejahtera 2, Ulu Siau & 235,83 & 247,21 & 21,60 & 86,36 & 0,37 & 0,25 \\
\hline 6 & Masangko & 255,00 & 268,00 & 59,60 & 80,00 & 0,31 & 0,75 \\
\hline 7 & Talang & 378,00 & 388,00 & 72,90 & 100,00 & 0,26 & 0,73 \\
\hline 8 & Malalugis & 450,00 & 460,00 & 84,40 & 100,00 & 0,22 & 0,84 \\
\hline 9 & Layang, Manado & 314,00 & 322,00 & 69,05 & 100,00 & 0,32 & 0,69 \\
\hline 10 & Kaisar Laut 1, Molompar & 237,00 & 237,00 & 47,54 & 72,00 & 0,30 & 0,66 \\
\hline 11 & Betsaida & 392,00 & 395,00 & 47,92 & 95,90 & 0,24 & 0,50 \\
\hline 12 & Batusaiki, Bunaken & 397,00 & 378,20 & 61,66 & 86,80 & 0,39 & 0,71 \\
\hline 13 & Mahengetang, Sangihe & 400,00 & 400,00 & 32,00 & 80,00 & 0,20 & 0,40 \\
\hline 14 & Lehoma, Batusaiki & 255,00 & 265,00 & 56,00 & 80,00 & 0,31 & 0,70 \\
\hline
\end{tabular}


Estimasi penggunaan bahan jarang dan panjang tali pemberat pada pukat cincin kecil

Tabel 2. Distribusi hang-in ratio dan besar mata pukat cincin kecil di Sulawesi Utara

\begin{tabular}{|c|c|c|c|c|c|c|c|c|c|c|c|c|c|c|c|}
\hline \multirow{3}{*}{$\begin{array}{l}\text { No } \\
1\end{array}$} & \multirow{3}{*}{$\begin{array}{c}\begin{array}{c}\text { Nama Pukat } \\
\text { Cincin }\end{array} \\
\text { Motabang }\end{array}$} & \multicolumn{7}{|c|}{ Hang-in Ratio(\%) } & \multicolumn{7}{|c|}{ Besar Mata (inci) } \\
\hline & & \multirow{2}{*}{$\begin{array}{c}\text { Sayap } \\
30\end{array}$} & \multicolumn{2}{|c|}{ Bahu } & \multirow[t]{2}{*}{ Perut } & \multicolumn{3}{|c|}{ Kantong } & \multirow{2}{*}{$\begin{array}{c}\text { Sayap } \\
13 / 4\end{array}$} & \multicolumn{2}{|c|}{ Bahu } & \multirow[t]{2}{*}{ Perut } & \multicolumn{3}{|c|}{ Kantong } \\
\hline & & & & & & 40 & & 40 & & & & & & 1 & \\
\hline 2 & Filadelfia & 30 & 35 & & 40 & & 45 & & 2 & $1 \frac{1 / 2}{2}$ & & 1 & & $3 / 4$ & \\
\hline 3 & Dunia.Bulat I & 27,2 & 27,7 & & & 31 & 15 & 31 & $11 / 4$ & 1 & & & 1 & $3 / 4$ & 1 \\
\hline 4 & Kaisar Laut 2 & 30 & 30 & & 30 & 30 & 34 & 30 & 2 & $1 \frac{1}{2}$ & & $1 \frac{1}{4}$ & 1 & $3 / 4$ & 1 \\
\hline 5 & Sejahtera 2 & 37 & 43 & 23 & 23 & 43 & 29 & 29 & 2 & $1 \frac{1 / 2}{2}$ & $1 \frac{11}{4}$ & $1 \frac{1}{2}$ & 1 & $1 \frac{1}{4}$ & $1 \frac{1 / 2}{2}$ \\
\hline 6 & Masangko & 40 & 40 & & 40 & 40 & 50 & 40 & 2 & $1 \frac{1}{2}$ & & $1 \frac{1}{4}$ & 1 & 1 & 1 \\
\hline 7 & Layang & 40 & 40 & 40 & 40 & 40 & 50 & 40 & 2 & $1 \frac{1}{2}$ & & $1 \frac{1}{4}$ & 1 & 1 & \\
\hline 8 & Malalugis & 35 & 40 & & 40 & 40 & 48 & 40 & 2 & $1 \frac{1}{2}$ & $1 \frac{1}{4}$ & 2 & 1 & 1 & \\
\hline 9 & Talang & 40 & 40 & & 40 & 50 & 40 & 50 & 2 & $1 \frac{1}{2}$ & & $1 \frac{1}{4}$ & 1 & 1 & 1 \\
\hline 10 & Kaisar Laut 1 & 30 & 30 & & 30 & 30 & 34 & 30 & 2 & $1 \frac{1}{2}$ & & $1 \frac{1}{4}$ & 1 & $3 / 4$ & 1 \\
\hline 11 & Lehoma & 40 & 40 & & 40 & 50 & 50 & 50 & 2 & $1 \frac{1}{2}$ & & $1 \frac{11 / 4}{2} \ln$ & 1 & 1 & 1 \\
\hline 12 & Betsaida & 40 & 43 & & 39 & & 24 & & 2 & $1 \frac{1 / 2}{2}$ & & $1 \frac{11 / 4}{2}$ & & 1 & \\
\hline 13 & Batusaiki & 40 & 40 & & 40 & 40 & 50 & 40 & 2 & $1 \frac{1}{2}$ & & $1 \frac{1}{4}$ & 1 & 1 & 1 \\
\hline 14 & Mahengetang & 20 & 30 & & & 40 & & & $1 \frac{1 / 2}{2}$ & $1 \frac{114}{4}$ & & & & 1 & \\
\hline
\end{tabular}

Hasil perhitungan nilai penggantungan jaring pada bagian tengah jaring atau kantong mulai dari $15 \%$ sampai dengan 50\%, sehingga lebar jaring pada bagian ini berkisar 53\% sampai dengan $86 \%$ dari jaring yang terentang sempurna. Nilai penggantungan terendah pada bagian kantong terdapat pada pukat cincin kecil Dunia Bulat I $(15 \%)$, sedangkan nilai penggantungan tertinggi terdapat pada pukat cincin kecil Lehoma, Talang dan Layang (50\%).

Pada bagian bahu dan perut nilai penggantungannya berkisar antara $27,2 \%$ sampai dengan $43 \%$, yang berarti bahwa lebar jaring mencapai $68,5 \%$ sampai dengan $82 \%$ dari jaring yang terentang sempurna. Nilai penggantungan terendah pada bagian bahu dan perut ditemukan pada pukat cincin kecil Dunia Bulat I $(27,2 \%)$, sedangkan nilai penggantungan tertinggi terdapat pada pukat cincin Sejahtra 2 dan Betsaida (43\%).

Untuk nilai penggantungan pada bagian sayap, kisarannya mulai dari $20 \%$ sampai dengan $40 \%$, yang memberi kontribusi kedalaman jaring $60 \%$ sampai dengan $80 \%$. Dengan nilai penggantungan terendah pada pukat cincin kecil Mahengetang Kabupaten Sangihe sebesar 20\%, dan nilai penggantungan terbesar pada bagian sayap yaitu 40\% digunakan oleh 5 pukat cincin kecil, yakni Talang, Layang, Batusaiki, Betsaida dan Lehoma.

Perbandingan lebar kantong dan panjang jaring.

Lebar jaring pada kebanyakan pukat cincin adalah $1 / 7-1 / 10$ atau $0,10-0,14$ lebih kecil dari pada panjangnya, tetapi pada daerah tenang, $1 / 15-1 / 20$ atau $0,05-0,06$ dari panjangnya. Sebaliknya pada ikan yang berenang pada perairan dalam atau menyelam dengan cepat dibuat lebar jaring 1/4-1/3 atau 0,25-0,33 dari panjangnya. Perbandingan lebar dan panjang jaring dikenal dengan nilai $k$. Jika nilai $k$ terlalu kecil, maka menjadikan jaring menyerupai papan. Apabila penarikan tali kolor dilakukan, maka akan menyebabkan pelampung tenggelam ke dalam laut sebagai akibat tegangan yang terjadi pada tali pelampung yang bersebrangan dengan kapal pukat cincin. Sebaliknya. terlalu besar nilai $k$ akan menyebabkan kesukaran dalam penanganan di atas kapal. Umumnya didapatkan nilai $k=0,08-0,20$, tetapi nilai $k$ kadang-kadang bertambah menjadi lebih besar dari pada 0,30 pada pukat cincin yang menangkap ikan horse mackerel dan mackerel yang dioperasikan pada waktu malam hari (Katiandagho, 1985).

Nilai $k$ pada beberapa pukat cincin kecil yang ada di Sulawesi Utara ditampilkan dalam Tabel 1. Keseluruhan pukat cincin kecil yang ada, mempunyai nilai $k$ di atas 0,20 yang separuhnya atau 50\% mempunyai nilai $k$ sama atau lebih dari 0,30 . Sedangkan separuhnya lagi mempunyai nilai $k 0,20$ sampai dengan 0,30 . Rata-rata nilai $k$ dari keseluruhan pukat cincin kecil yang ada adalah 0,28 . Hasil perbandingan ini menunjukkan bahwa hampir keseluruhan pukat cincin kecil ini, termasuk pada kategori pukat cincin yang dioperasikan pada malam hari.

\section{Hubungan lebar kantong dan panjang tali samping}

Tali samping (breast line) pada pukat cincin biasanya mempunyai lebar $0,40-0,60$ dari lebar 
kantong. Nilai perbandingan ini didapatkan dengan membandingkan panjang tali samping dengan lebar kantong dalam keadaan terentang sempurna.

Perbandingan panjang tali samping dan lebar kantong pada beberapa pukat cincin kecil (Tabel 1) menunjukkan nilai yang cenderung lebih besar dari 0,6 , yakni sebanyak $64,28 \%$ atau pada sembilan pukat cincin. Sedangkan pukat cincin kecil yang mempunyai nilai perbandingan signifikan yakni Mahengetang $(0,40)$, Filadelfia $(0,50)$, Betsaida
$(0,50)$ dan Dunia Bulat I $(0,58)$. Hanya satu pukat cincin yang mempunyai nilai perbandingan yang rendah yakni Sejahtera 2 dengan nilai 0,25. Untuk nilai perbandingan tertinggi terdapat pada pukat cincin Masangko dengan nilai sebesar 0,73.

Besaran nilai perbandingan panjang tali samping dan lebar kantong pada masing-masing jaring yang diukur dibandingkan dengan nilai perbandingan proporsional $0,40-0,60$ yang ditampilkan dalam bentuk grafik pada Gbr. 1.

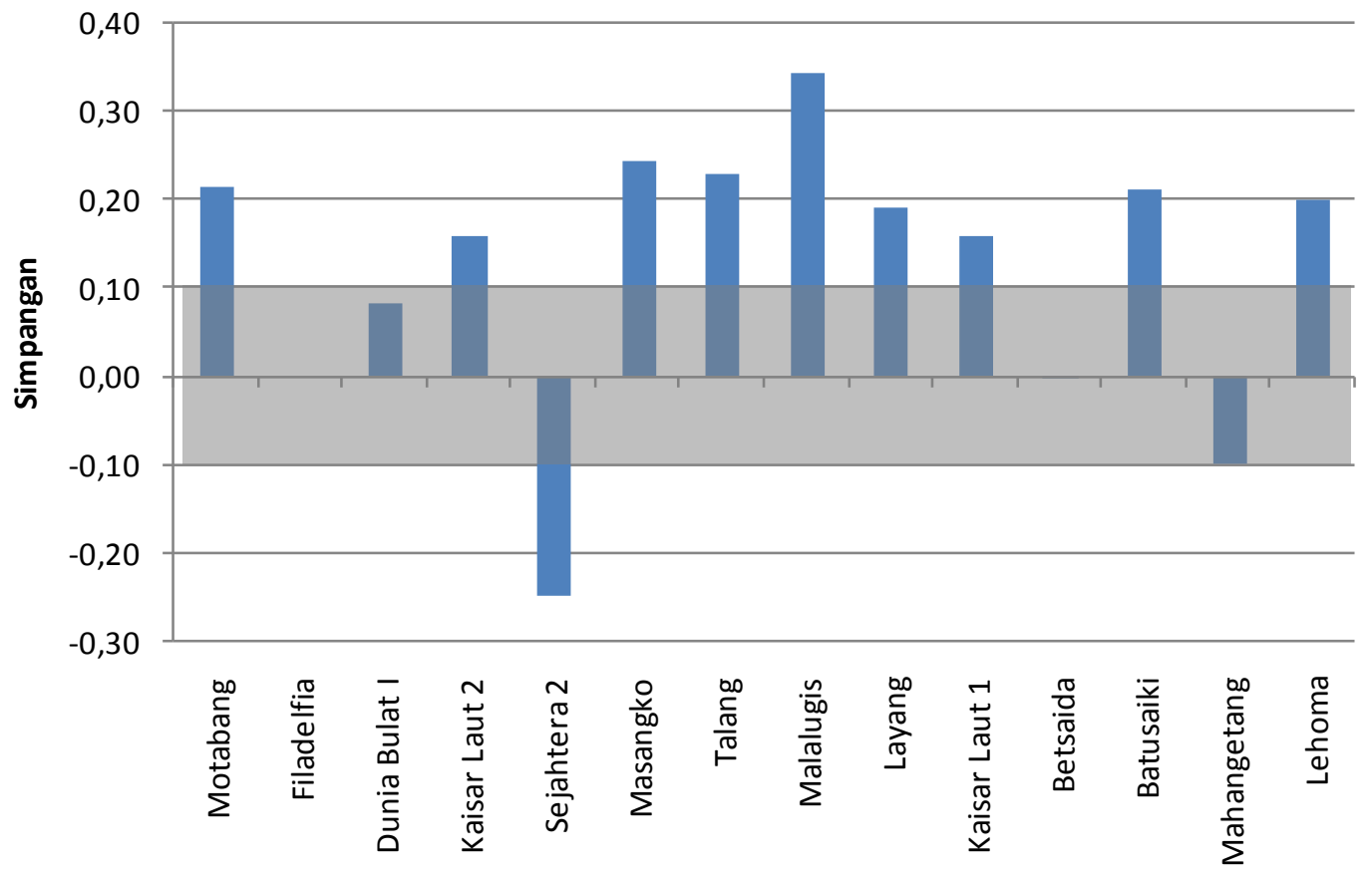

Pukat Cincin

Gambar 1. Simpangan perbandingan panjang tali samping dengan lebar kantong terhadap nilai proporsional 0,40-0,60

Dari Gbr. 1 terlihat bahwa 28,57\% pukat cincin kecil termasuk dalam kategori nilai perbandingan proporsional, $7,14 \%$ berada di bawah nilai proporsional dengan besar simpangan 0,15 dan 64, $29 \%$ memiliki nilai perbandingan di atas nilai proporsional dengan besaran simpangan mulai dari 0,05 sampai dengan 0,15 . Besaran nilai simpangan ini dihitung dari batas bawah 0,40 dan batas atas 0,60 yang pada grafik ditandai dengan arsiran yang merupakan nilai wilayah proporsional. Nilai simpangan yang muncul pada grafik ini, berdasarkan nilai patokan 0,50 .

\section{Sisi miring dan panjang tali pemberat}

Lebar sayap pada pukat cincin, biasanya lebih kecil dibandingkan dengan lebar kantong. Dalam pembuatannya disiasati dengan mengurangi jumlah mata jaring ke arah bagian dalam atau lebar pada setiap lembarannya mulai dari bagian yang berdampingan dengan kantong sampai bagian ujung sayap baik pada sisi kiri maupun kanan jaring dengan bentuk penurunan bertangga.

Dari 14 buah pukat cincin kecil yang diukur dan diamati, terdapat dua buah pukat cincin yang melakukan pemotongan miring badan jaring yang melekat pada tali pemberat yaitu Mahengetang dan Filadelfia. Sedangkan 11 pukat cincin lainnya tidak melakukan pemotongan miring, walaupun terjadi 
perbedaan lebar pada masing-masing bagian jaring mulai dari tepi kantong sampai ke bagian ujung sayap yaitu pada tali samping.

Perbedaan kedalaman/lebar jaring akan membentuk bidang trapesium siku-siku, di mana sisi miringnya melekat pada tali pemberat. Akibat perlakuan ini, luasan bidang yang terbentuk tidaklah sama. Maka seharusnya juga, panjang tali pemberat akan lebih panjang dari tali pelampung.

Pukat cincin Motabang, adalah satu-satunya yang memiliki lebar yang sama pada keseluruhan bagian jaring setelah tertata yakni 75 meter, sehingga panjang tali pelampung dan panjang tali pemberatnya sama. Sedangkan yang lainnya memiliki perbedaan lebar yang bervariasi (Tabel 1).

Perbedaan kedalaman jaring yang makin mengecil ke arah tali samping, akan menempatkan sisi miring bidang trapesium sebagai panjang tali pemberat, sedangkan tali pelampung adalah sumbu $x$ dan tinggi jaring adalah sumbu $y$. Besarnya pertambahan panjang sisi miring atau tali pemberat, tergantung pada panjang tali pelampung dan selisih lebar jaring dari bagian terlebar dengan bagian terkecil.

Luasan bidang trapesium yang terbentuk, adalah jumlah badan jaring yang seharusnya digunakan. Dari hasil pengamatan, jumlah jaring yang digunakan untuk menutupi area ini, tidak sesuai pada sebagian besar pukat cincin yang diukur. Hal ini terjadi karena panjang sisi miring yang terbentuk akibat perbedaan lebar jaring, tidak proporsional pertambahannya sesuai dengan selisih kedalaman jaring bagian terlebar dan bagian terpendek. Selain itu, perbedaan jumlah mata jaring ke arah lebar yang berbeda, disiasati dengan melakukan gathering, sehingga jumlah mata jaring arah horizontal tetap sama. Seharusnya pada bagian ini dilakukan pemotongan miring untuk mendapatkan bentuk sesuai dengan perbedaan lebar yang ada.

Tabel 3 menunjukkan hasil perhitungan luasan jaring yang terpasang pada setiap pukat cincin yang diamati beserta panjang tali pemberatnya dan dibandingkan dengan hasil analisis untuk mendapatkan luas jaring yang seharusnya digunakan untuk menutupi bidang yang terbentuk, serta estimasi cutting ratio yang harus diterapkan untuk mendapatkan bentuk sisi miring yang sesuai bagi masing-masing pukat cincin yang diamati.

Hasil estimasi luasan jaring dan panjang tali pemberat didasarkan pada bentuk asli jaring yang diamati, tanpa menambah lebar kantong maupun panjang tali samping. Terdapatnya selisih luas bidang jaring dan perbedaan panjang tali pemberat, sangat bervariasi tergantung pada besaran selisih panjang tali samping dan lebar kantong dalam keadaan terentang. Semakin kecil nilai perbandingannya, maka akan semakin besar nilai pertambahan panjang tali pemberat dan besaran selisih luasan jaring yang digunakan.

Luas bidang yang tertera dalam tabel terdiri dari dua yakni luas keseluruhan bidang yang dibentuk oleh jaring berdasarkan hasil pengukuran setiap lembaran jaring yang digunakan dalam keadaan tertata, dan luas bidang berdasarkan hasil estimasi dengan berpatokan pada panjang dan lebar jaring serta nilai penggantungan pada masing-masing bagiannya, kemudian dihitung cutting ratio berdasarkan jumlah mata jaring yang digunakan baik arah horizontal maupun selisih arah vertikalnya.

Setelah dilakukan analisis dari hasil pengukuran penggunaan bahan untuk badan jaring, maka terlihat bahwa penggunaan terluas terdapat pada pukat cincin Dunia Bulat I yakni sebesar $1386,48 \mathrm{~m}^{2}$ dari yang seharusnya digunakan berdasarkan hasil analisis yaitu seluas $9754,85 \mathrm{~m}^{2}$. Ini menunjukkan bahwa pukat cincin ini dibuat dengan kekurangan bahan untuk badan jaring sebesar $14,21 \%$. Sedangkan untuk penggunaan tali pemberat, kekurangan $10,14 \mathrm{~m}$ dari yang seharusnya digunakan atau kurang 3,57\%. Sejahtera 2 kekurangan bahan untuk badan jaring seluas $767,29 \mathrm{~m}^{2}$ dari luas yang seharusnya atau sebesar 7,23\% dan kekurangan 8,16 $\mathrm{m}$ tali pemberat $(3,19 \%)$. Filadelfia kelebihan dalam pemakaian bahan jaring seluas $750,43 \mathrm{~m}^{2}(5,40 \%)$ dan lebih dalam penggunaan tali pemberat sepanjang $9,78 \mathrm{~m}$ $(3,27 \%)$. Kaisar Laut 1 kelebihan dalam penggunaan bahan jaring seluas 1190,35 $\mathrm{m}^{2}$ $(10,35 \%)$ dan kurang dalam penggunaan tali pemberat sepanjang $8,08 \mathrm{~m}(2,87 \%)$. Lehoma menggunakan bahan jaring dengan kelebihan seluas $67,81 \mathrm{~m}^{2}(0,43 \%)$ dan kurang dalam penggunaan tali pemberat sepanjang $0,8 \mathrm{~m}(0,3 \%)$. Motabang Bolaang mongondow, tidak ada perbedaan penggunaan luasan jaring maupun pemakaian tali pemberat antara hasil pengukuran dan analisis, karena pukat cincin ini mempunyai lebar yang sama dan merata pada keseluruhan bagian jaring. Layang, lebih dalam 


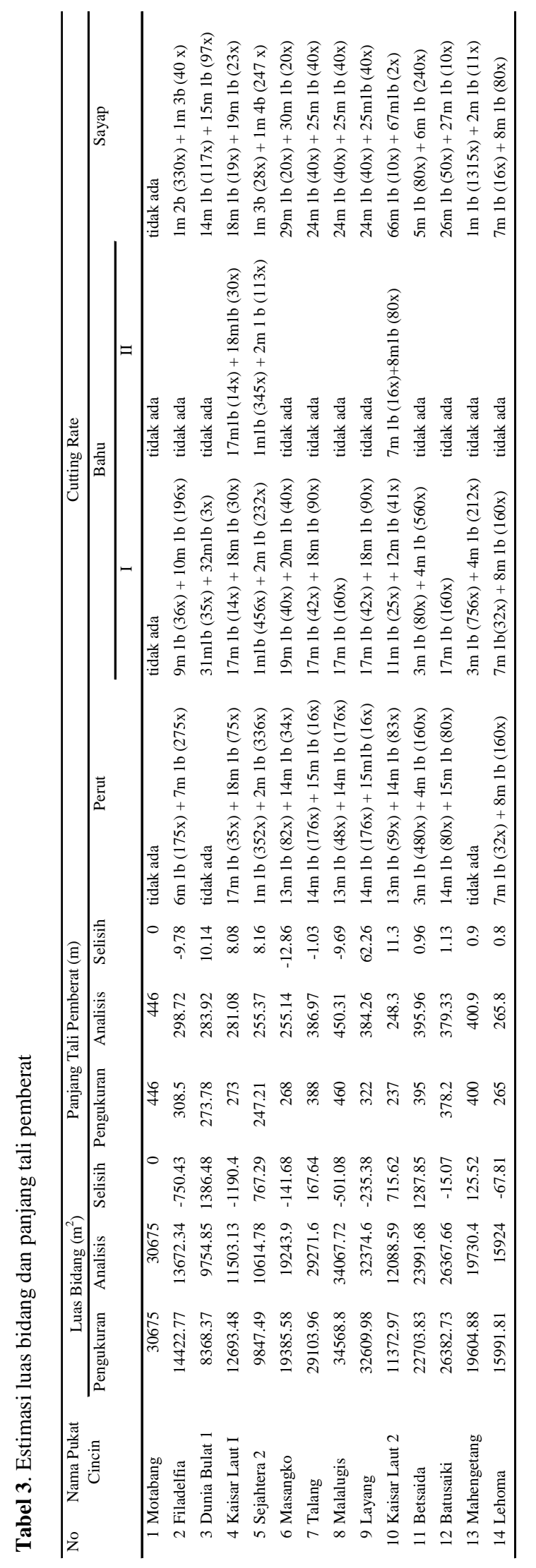


penggunaan bahan untuk badan jaring seluas $235,38 \mathrm{~m}^{2}(3,95 \%)$ dan lebih dalam penggunaan tali pemberat sepanjang $15,74 \mathrm{~m}(4,09 \%)$. Kaisar Laut 2 dalam penggunaan bahan jaring kurang seluas $715,62 \mathrm{~m}^{2}(5,92 \%)$ dan juga kurang dalam pemakaian tali pemberat sepanjang $11,3 \mathrm{~m}(4,55 \%)$. Mahengetang kurang bahan badan jaring seluas $125,52 \mathrm{~m}^{2}(0,64 \%)$ dan kurang dalam pemakaian tali pemberat sepanjang $0,9 \mathrm{~m}(0,22 \%)$. Betsaida kurang bahan jaring seluas $1287,85 \mathrm{~m}^{2}(5,37 \%)$ dan kurang sepanjang $3,95 \mathrm{~m}(0,99 \%)$ pada tali pemberat. Batusaiki kelebihan seluas $15,07 \mathrm{~m}^{2}$ $(0,06 \%)$ luasan badan jaring dan kurang $1,13 \mathrm{~m}$ $(0,3 \%)$ pada tali pemberat. Masangko kelebihan bahan jaring seluas $141,68 \mathrm{~m}^{2}(0,74 \%)$ juga kelebihan dalam penggunaan tali pemberat sepanjang 12,36 m (4,84\%). Talang kekurangan luasan jaring $167,64 \mathrm{~m}^{2}(0,57 \%)$ dan lebih dalam penggunaan tali pemberat sepanjang $1,03 \mathrm{~m}$ $(0,27 \%)$. Malalugis lebih dalam penggunaan bahan untuk badan jaring seluas 501,08 $\mathrm{m}^{2}(1,47 \%)$ dan kurang dalam penggunaan tali pemberat sepanjang 9,69 m (2,15\%).

Pada Tabel 3 terlihat bahwa ada 7 pukat cincin yang penggunaan bahan untuk badan jaring lebih dibandingkan hasil analisis yang nilainya bervariasi mulai dari 501,08 $\mathrm{m}^{2}$ (Malalugis) sampai dengan $1386,48 \mathrm{~m}^{2}$ (Dunia Bulat I). untuk kekurangan bahan jaring, nilainya mulai dari $15,07 \mathrm{~m}^{2}$ (Batusaiki) sampai dengan kekurangan 1190,35 $\mathrm{m}^{2}$ (Kaisar Laut 1).

Untuk memberikan gambaran yang lebih jelas, seberapa besar persentasi selisih luas penggunaan bahan jaring antara hasil pengukuran dengan hasil analisis, dituangkan dalam bentuk grafik persentasi Gbr. 2.

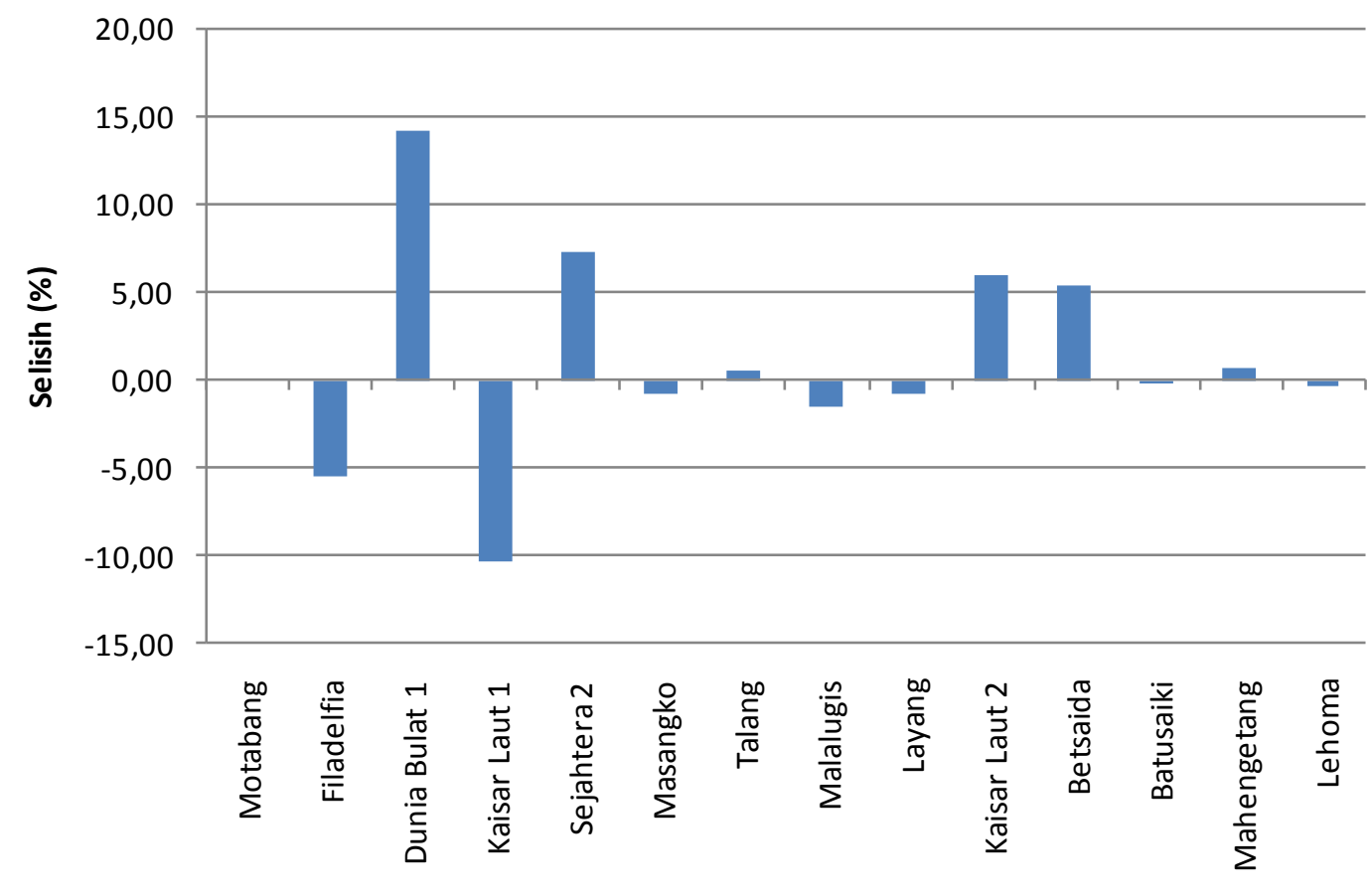

Pukat Cincin

Gambar 2. Persentasi selisih penggunaan bahan jaring terhadap nilai analisis

Persentasi selisih luasan bidang jaring antara hasil analisis dengan hasil pengukuran pada Gbr. 2 tersebar sepanjang sisi miring yakni pada tali pemberat. Kelebihan maupun kekurangan bahan untuk badan jaring dapat direduksi dengan menerapkan pemotongan miring. Kombinasi cutting ratio untuk setiap pukat cincin kecil yang diamati, tercantum dalam Tabel 3, di mana setiap bagian mempunyai kombinasi pemotongan yang berbeda. Tujuan pemotongan miring adalah untuk penyederhanaan bentuk jaring yang akan disatukan dengan selambar (selvedge) pada bagian tali 
pemberat. Karena besar mata jaring adalah 2 kali panjang bar, maka selisih jumlah mata jaring arah vertikal akan menjadikan jumlah bar sebanyak dua kali dari selisih itu, untuk mendapatkan kemiringan yang sesuai pada setiap bagiannya.

Gambar 3 menunjukkan hasil analisis panjang tali pemberat yang seharusnya digunakan berdasarkan bentuk jaring setelah dilakukan pemotongan miring untuk mendapatkan bentuk sesuai dengan bentuk pukat cincin yang diamati. Hasilnya dibandingkan dengan panjang tali pem-berat yang telah terpasang.
Kisaran selisih panjang tali pemberat yang terpasang dibandingkan dengan hasil analisis menunjukkan bahwa lima buah pukat cincin, panjang tali pemberat yang terpasang kurang, dengan kisaran mulai dari 0,66\% (Malalugis) sampai dengan $31,92 \%$ (Betsaida). Delapan pukat cincin mempunyai kelebihan panjang mulai dari $0,002 \%$ (Talang) sampai dengan $0,48 \%$ (Masangko), sedangkan pukat cincin Motabang tidak ada perbedaan.

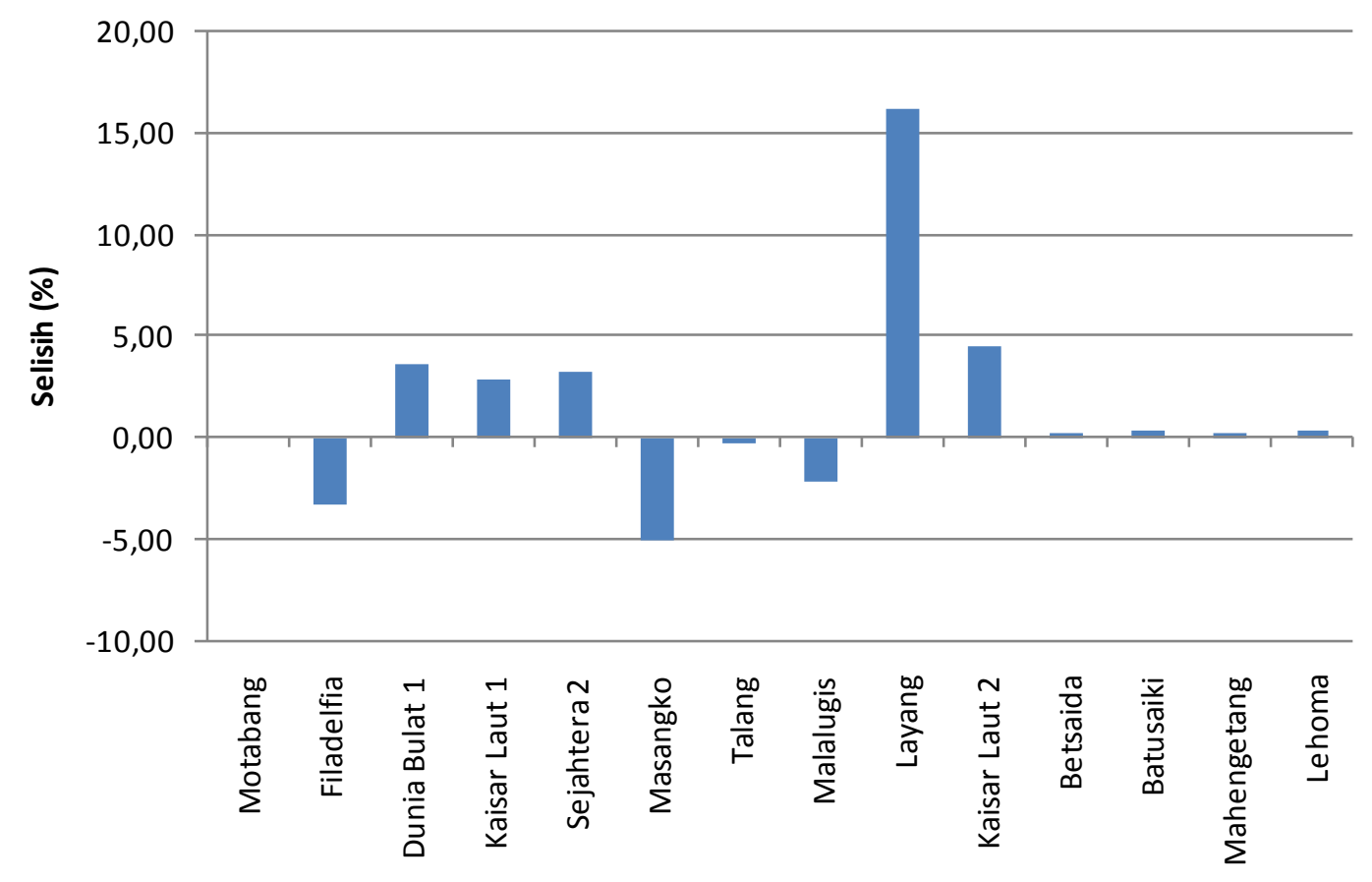

Pukat Cincin

Gambar 3. Persentasi selisih panjang tali pemberat hasil analisis dengan tali pemberat terpasang

\section{KESIMPULAN}

Sisi miring dapat terbentuk pada jaring didapatkan dengan mencari cutting ratio berdasarkan selisih jumlah mata vertikal sebagai ketinggian jaring dan horizontal sebagai panjang jaring.

Hasil analisis menunjukkan terdapat kelebihan pemakaian bahan jaring pada sembilan buah pukat cincin kecil dan kekurangan bahan pada empat buah. Panjang tali pemberat tidak sama antara hasil analisis dengan panjang tali yang terpasang pada pukat cincin kecil yang diamati kecuali pukat cincin Motabang.

\section{UCAPAN TERIMA KASIH}

Tulisan ini dibuat sebagai rasa terima kasih buat Ir. E.M. Katiandagho, M.Sc. yang banyak membantu penulis dalam penelitian tentang pukat cincin. $O$ Tsukaresama Deshita. 


\section{DAFTAR PUSTAKA}

Arikunto S, 1998. Prosedur penelitian Suatu Pendekatan Praktek. Rineka Cipta, Jakarta.

Fridman A.L. 1988 Perhitungan dalam Merancang Alat Penangkap Ikan. Balai Pengembangan Penangkapan Ikan, Semarang.

Fridman A.L. 1986. Calculation for Fishing Gear Designs. Published by Arrangement with the Food and Agriculture
Organization of The United Nations by Fishing News Books, Oxford.

Katiandagho E.M. 1990. Purse seine. Fakultas Perikanan Universitas Sam Ratulangi, Manado.

Nomura, M and T.Yamazaki. 1977. Fishing Techniques (1). Japan International Cooperation Agency, Tokyo.

Prado, Y and P.Y. Dremiere. 1990. Fisherman's Workbook. FAO of the United Nations. Fishing News Books, Oxford. 